Our results show that salbutamol given by IPPB is more effective in relieving pulsus paradoxus than salbutamol given by intravenous injection. Pulsus paradoxus in asthma reflects abnormal intrathoracic pressures produced by airways obstruction, and hence its relief is an important index of improvement. Direct measurement of airways obstruction using the PEFR indicated that significant relief occurred after both treatments but with no statistical difference between the two methods. It is difficult to explain why there was such a pronounced difference between the two treatments in relieving pulsus paradoxus but little difference in their effect on the PEFR. Pulsus paradoxus is a valuable sign indicating severe asthma and correlates well with other objective and clinical assessments. ${ }^{6}$ Woolcock and Reid ${ }^{7}$ showed that a reduction in lung volumes and a consequent reduction in the elastic work of inspiration after administration of bronchodilator drugs to patients with acute asthma may precede improvement in the forced expiratory volume. Our results suggest that relief of pulsus paradoxus may be a more sensitive index of improvement in acute asthma than simple measurements of ventilatory function such as PEFR and forced expiratory volume. We think it unlikely that the difference between treatments may be wholly explained by a direct cardiovascular effect of intravenous salbutamol. Previous trials of drugs in severe acute asthma have not used pulsus paradoxus as an objective index of response to treatment, and this may prove to be a useful measurement for similar trials in the future.

No undesirable side effects were reported by patients after administration by IPPB, but four patients had palpitations and tremor after they had been given salbutamol intravenously. Both patients withdrawn from the trial within the first treatment hour because of a worsening clinical condition had received intravenous salbutamol. Intravenous salbutamol induced a mean increase in heart rate of over 20 beats/min compared with the relief of tachycardia observed after the drug was given by IPPB. We used a large dose of intravenous salbutamol, but similar heart-rate responses have been recorded when lower doses have been given by intravenous injection, and also when the drug has been given by a constant infusion. ${ }^{45} 8$

We conclude that because of its greater efficacy and freedom from side effects $0.5 \%$ salbutamol administered by IPPB for three minutes is superior to $500 \mu \mathrm{g}$ salbutamol given by intravenous injection over three minutes in treating patients with severe asthma.

We should like to thank Allen \& Hanburys Ltd for supplying the salbutamol, and Miss J Williamson for typing the manuscript.

\section{References}

1 Crompton, G K, British fournal of Diseases of the Chest, 1977, 71, 242.

2 Williams, S J, Parrish, R W, and Seaton, A, British Medical fournal, 1975, 4, 685 .

3 Hetzel, M R, and Clark, T J H, British Medical fournal, 1976, 2, 919.

${ }^{4}$ Lawford, P, Jones, B J M, and Milledge, J S, British Medical fournal, 1978, 1,84 .

5 Williams, S, and Seaton, A, Thorax, 1977, 32, 555.

${ }^{6}$ Knowles, G K, and Clark, T J H, Lancet, 1973, 2, 1357.

7 Woolcock, A J, and Reid, J, Lancet, 1965, 2, 1323.

${ }^{8}$ Fitchett, D H, McNichol, M W, and Riordan, J F, British Medical fournal, $1975,1,53$

\title{
Changes in fatty-acid composition of body fat before and after birth in Tanzania: an international comparative study
}

\author{
E R BOERSMA
}

British Medical fournal, 1979, 1, 850-853

\section{Summary and conclusions}

Changes in the fatty-acid composition of human adipose tissue before birth and during infancy and childhood were studied in Tanzania and compared with data for British and Dutch infants in relation to their diet. From the 32nd to the 37th week of gestation in Tanzania the proportion in the body fat of the unsaturated fatty acid linoleic acid tended to rise, suggesting an adequate supply of this essential fatty acid from the mother to the fetus. At term $2.5 \%$ of the total fatty acids of the body fat was linoleic acid, which corresponded with values in Dutch newborn infants but was significantly higher than those in British infants. During infancy in Tanzania the composition of the fat showed a dramatic increase in the proportions of the saturated fatty acids lauric acid and

Department of Paediatrics, Muhimbili Medical Centre, Dar es Salaam, Tanzania

E R BOERSMA, MD, senior lecturer (present address: Department of Paediatrics, subdivision of neonatology, Erasmus University and Academic Hospital, Sophia Children's Hospital, Rotterdam, The Netherlands) myristic acid, which did not occur in Dutch and British infants. The proportion of linoleic acid increased to $8 \%$. These changes were a reflection of the fatty-acid composition of the fat in the human milk that the infants received. During weaning (1-2 years of age) the fattyacid composition changed only slightly.

The specific fatty-acid composition of the fat in Tanzanian breast milk may have a beneficial influence on the extent of intestinal absorption in the newborn child.

\section{Introduction}

In Tanzania and the other developing countries of Africa the incidence of arteriosclerosis is low. Establishing a correlation between the quality and quantity of fat intake during childhood and the genesis of risk factors for arteriosclerosis in adult life is difficult, as is shown by the controversial findings of several studies. ${ }^{1-5}$ Dietary fat in young infants not only serves as the most important source of energy but also contains nutrients essential for normal growth and development. The nature of the fat consumed in terms of the proportions of fatty acids and their different chain lengths can have an important influence on the fatty-acid composition of adipose tissue ${ }^{6}$ and human milk fat, ? but probably not on the composition of lipids in cell membranes and nervous tissue. Since diets are subject to custom as well as to socioeconomic circumstances, comparing the fatty-acid 
composition of adipose tissue in different countries may yield useful information, particularly during intrauterine life and infancy.

I studied changes in the fatty-acid composition of human adipose tissue before birth, during infancy, and during childhood. I compared analyses of subcutaneous fat samples from the thigh of Tanzanian infants with data on British and Dutch infants. ${ }^{6}$ I also evaluated the effects of the gestational age and nutritional state on the composition of fatty acids in adipose tissue of Tanzanian fetuses.

\section{Patients and methods}

Samples of adipose tissue from the thigh were obtained from 10 preterm infants whose birth weights were appropriate for their gestational age-that is, within the mean $\pm 1 S D$ weight for gestational age according to local standards ${ }^{8}$; from nine infants who were small for dates-that is, whose birth weights were below the 10th percentile for gestational age according to local standards; and from nine infants, born at term with birth weights appropriate for gestational age, within four hours after perinatal death. The gestational ages of the preterm infants varied from 28 to 36 weeks (average 34 weeks); those of the small-for-dates infants varied from 32 to $\mathbf{4 0}$ weeks (average 35 weeks). Assessment of the gestational age was based on physical characteristics according to a scheme suggested by Lubchenco ${ }^{9}$ adapted for the skin colour of negro children. ${ }^{8}$ Subcutaneous fat tissue was also obtained from the thigh in 15 children (aged from 3 weeks to 2 years) who had died; only two of them ( 1 and 2 years old) showed appreciable evidence of malnutrition (kwashiorkor). All patients studied were admitted to the Muhimbili Medical Centre. Table I shows the different groups of children studied and their sources of dietary fat.

TABLE I-Groups of infants studied and sources of dietary fat

\begin{tabular}{|c|c|c|c|}
\hline Group & Age & No of infants & Diet \\
\hline $\left.\begin{array}{l}1 \\
2 \\
3 \\
4 \\
5\end{array}\right\}$ & 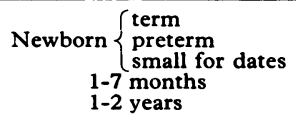 & $\begin{array}{r}9 \\
10 \\
9 \\
8 \\
6\end{array}$ & $\begin{array}{l}\text { Breast milk } \\
\text { Mixed }\end{array}$ \\
\hline
\end{tabular}

The samples of body fat (50-100 mg) were washed with isotonic saline and stored and transported at $-20^{\circ} \mathrm{C}$ until analysed. Milk specimens were collected by manual expression from 12 women living in urban and semi-urban areas within a 10-mile radius of Dar es Salaam; these samples were taken about one month after labour and stored and transported at $-20^{\circ} \mathrm{C}$ until analysed. All samples were analysed in the paediatric laboratory of the University of Groningen by the methods of Metcalfe et al ${ }^{10}$ and Lipsky et al. ${ }^{11}$

The statistical significance between means was measured by Student's $t$ test.

\section{Results}

Figure 1 shows the different fatty acids as percentages of the triglycerides in the total body fat of term, preterm, and small-for-dates infants plotted against gestational age. Table II shows the mean

TABLE II-Mean fatty-acid composition $( \pm S D$ ) of body fat in infants born at term and preterm with birth weights appropriate for gestational age and in small-for-dates. Tanzanian infants ( $\mathrm{g} / 100 \mathrm{~g}$ total fatty acids)

\begin{tabular}{|c|c|c|c|c|}
\hline \multicolumn{2}{|c|}{ Fatty acid } & $\begin{array}{c}\text { Term } \\
(\mathbf{n}=9)\end{array}$ & $\begin{array}{l}\text { Preterm } \\
(\mathbf{n}=10)\end{array}$ & $\begin{array}{c}\text { Small for dates } \\
(n=10)\end{array}$ \\
\hline $\begin{array}{l}\text { Lauric } \\
\text { Myristic } \\
\text { Palmitic } \\
\text { Stearic }\end{array}$ & $\begin{array}{l}(\mathrm{C} 12: 0) \\
(\mathrm{C} 14: 0) \\
(\mathrm{C} 16: 0) \\
(\mathrm{C} 18: 0)\end{array}$ & $\begin{array}{r}S \\
0.2 \pm 0.2 \\
4.3 \pm 1 \cdot 0 \\
48 \cdot 2 \pm 2 \cdot 2 \\
4.9 \pm 0.7\end{array}$ & $\begin{array}{l}\text { cids } \\
0 \\
4 \cdot 2 \pm 0 \cdot 4 \\
45 \cdot 7 \pm 4 \cdot 9 \\
5 \cdot 7 \pm 1 \cdot 2\end{array}$ & $\begin{array}{c}0 \\
4 \cdot 2 \pm 0 \cdot 8 \\
45 \cdot 5 \pm 4 \cdot 3 \\
5 \cdot 8 \pm 1 \cdot 9\end{array}$ \\
\hline $\begin{array}{l}\text { Palmitolei } \\
\text { Oleic } \\
\text { Linoleic }\end{array}$ & $\begin{array}{r}(\mathrm{C} 16: 1) \\
(\mathrm{C} 18: 1) \\
(\mathrm{C} 18: 2)\end{array}$ & $\begin{array}{rl}U n & U \\
12.7 & \pm 1 \cdot 4 \\
27.8 & \pm 2.9 \\
2 \cdot 3 & \pm 0.6\end{array}$ & $\begin{aligned} \text { acids } \\
12 \cdot 0 \pm 1 \cdot 9 \\
29 \cdot 5 \pm 4 \cdot 1 \\
2 \cdot 9 \pm 1 \cdot 0\end{aligned}$ & $\begin{array}{r}11 \cdot 8 \pm 2 \cdot 8 \\
30 \cdot 2 \pm 5 \cdot 1 \\
2 \cdot 6 \pm 1 \cdot 7\end{array}$ \\
\hline
\end{tabular}
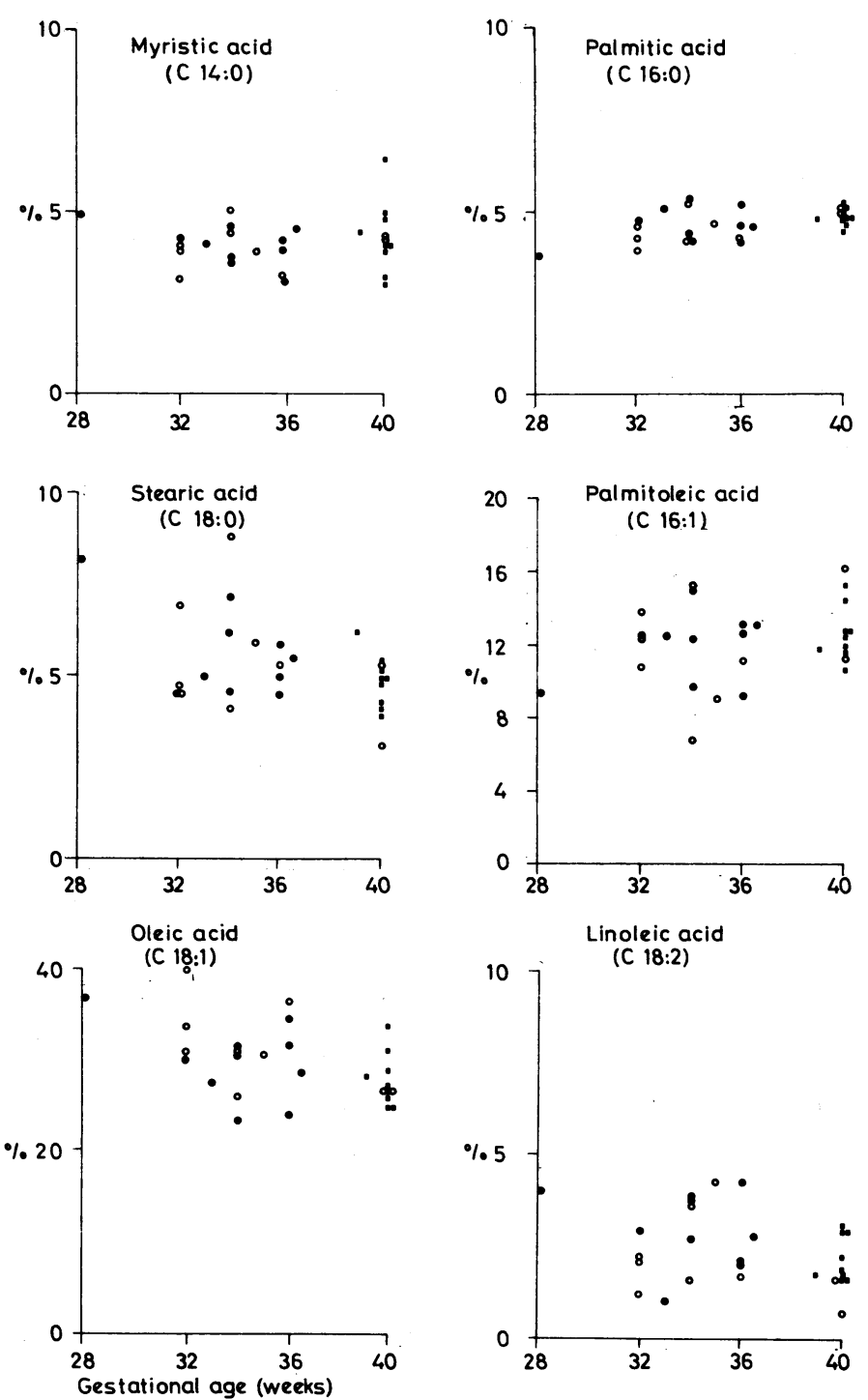

FIG 1-Individual fatty acids as percentages of total fatty acids in body fat of preterm, small-for-dates, and term infants in Tanzania related to gestational age.

$O=$ Preterm infants. $O=$ Infants small for dates. $\square=$ Term infants.

TABLE III-Ratios of unsaturated to saturated acids during last trimester in Tanzanian fetuses

\begin{tabular}{lllll}
\hline Gestational age in weeks & & $28-32$ & $33-36$ & $37-40$ \\
Unsaturated: saturated acids (No of fetuses) & $\ldots$ & $0.93(5)$ & $0.79(11)$ & $0.74(12)$
\end{tabular}

$( \pm S D)$ values in these infants at birth. The ratio of unsaturated to saturated fatty acids during the last trimester is shown in table III and indicates a trend for the body fat to become more saturated towards term. The percentage of the essential fatty acid linoleic acid (C18:2) seemed to increase between 32 and 37 weeks' gestation. At term the percentage correlated with values obtained in Dutch newborn infants but was significantly higher $(P<0.001)$ than those in British infants. Palmitic acid (C16:0) was the only fatty acid that correlated with gestational age during the last trimester $(r=0.530)$. No notable changes were observed during the last months of pregnancy in the other fatty acids studied. At term, however, the percentages of myristic acid (C14:0) and lauric acid (C12:0) were higher in Tanzanian newborn than in Dutch babies $(P<0.005)$. Palmitoleic acid $(\mathrm{C} 16: 1)$ was present in the same proportions in Tanzanian and British infants at term, this proportion being lower than that found in Dutch infants $(P<0.001)$. No notable differences were observed between the fatty-acid composition of preterm and small-for-dates babies of the same gestational age.

In figure 2 the individual fatty acids as percentages of the total fatty 

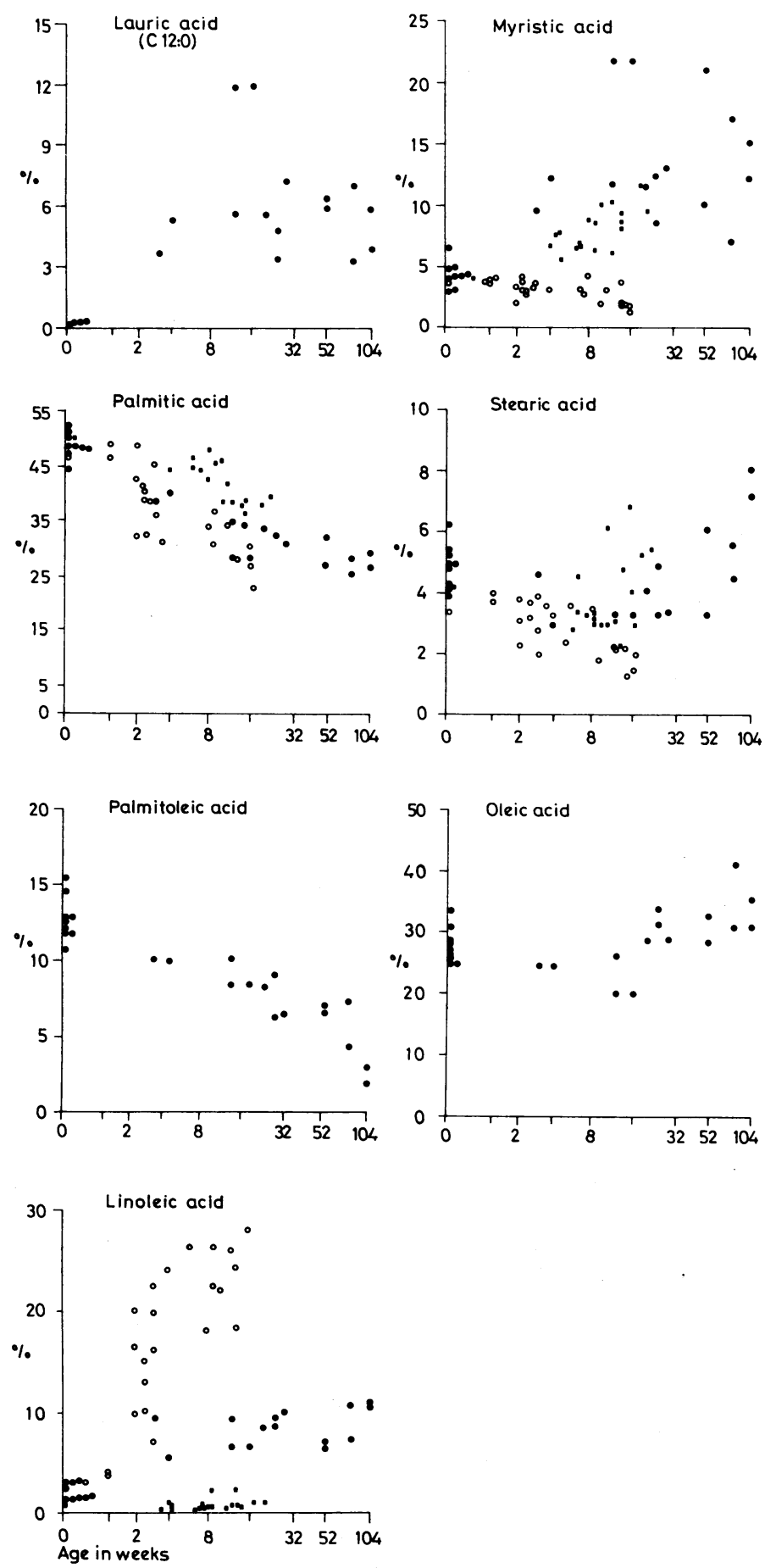

FIG 2-Individual fatty acids as percentages of total fatty acids in subcutaneous fat of Tanzanian, British, and Dutch infants. Data for British and Dutch infants obtained only for linoleic, myristic, palmitic, and stearic acids, from Widdowson et al. ${ }^{6}$

$O=$ Tanzanian infants. $\square=$ British infants. $O=$ Dutch infants.

acids in the subcutaneous fat of Tanzanian infants after birth up to the age of 2 years are plotted together with the values obtained in British and Dutch infants. ${ }^{6}$ Individual data were available only for linoleic, myristic, palmitic, and stearic (C18:0) acids in British infants up to the age of 5 months and Dutch infants up to the age of 6 months. Between 4 and 8 weeks after birth the fatty-acid composition of the body fat tended towards that of the milk given in each country.

Table IV shows the mean fatty-acid composition of the subcutaneous fat of Tanzanian infants at birth, during breast-feeding (1-7 months of age), and while receiving a mixed diet (1-2 years old). After birth the proportions of lauric and myristic acids increased considerably at the expense of the longer-chain palmitic acid $(P<0.001)$. Of the unsaturated fatty acids, the proportion of linoleic acid increased significantly to $8.1 \%(P<0.001)$ and the percentage of palmitoleic acid de-
TABLE IV-Mean fatty-acid composition $( \pm S D)$ of subcutaneous fat in nine Tanzanian infants at birth, eight breast-fed infants aged 1-7 months, and six children aged 1-2 years receiving a mixed diet ( $\mathrm{g} / 100 \mathrm{~g}$ total fatty acids)

\begin{tabular}{|c|c|c|c|}
\hline \multirow{2}{*}{ Fatty acid } & \multicolumn{3}{|c|}{ Age } \\
\hline & $\begin{array}{c}\text { At birth } \\
(\mathrm{n}=9)\end{array}$ & $\begin{array}{c}1-7 \text { months } \\
(n=8)\end{array}$ & $\begin{array}{c}1-2 \text { years } \\
(n=6)\end{array}$ \\
\hline $\begin{array}{l}\text { Lauric acid } \\
\text { Myristic acid } \\
\text { Palmitic acid } \\
\text { Stearic acid }\end{array}$ & $\begin{array}{r}S a \\
0 \cdot 2 \pm 0 \cdot 2^{*} \\
4 \cdot 3 \pm 1 \cdot 0^{*} \\
48 \cdot 2 \pm 2 \cdot 2^{*} \\
4 \cdot 9 \pm 0 \cdot 7^{*}\end{array}$ & $\begin{array}{l}\text { icids } \\
7 \cdot 0 \pm 3 \cdot 2 \\
14 \cdot 1 \pm 4 \cdot 9 \\
32 \cdot 2 \pm 3 \cdot 7^{* *} \\
3 \cdot 4 \pm 0 \cdot 8^{* * *}\end{array}$ & $\begin{array}{r}5 \cdot 4 \pm 1 \cdot 5 \\
13 \cdot 8 \pm 5 \cdot 0 \\
27 \cdot 9 \pm 2 \cdot 2 \\
5 \cdot 8 \pm 1 \cdot 8\end{array}$ \\
\hline $\begin{array}{l}\text { Palmitoleic acid } \\
\text { Oleic acid } \\
\text { Linoleic acid }\end{array}$ & $\begin{array}{r}U_{n s} \\
12 \cdot 7 \pm 1 \cdot 4^{*} \\
27 \cdot 8 \pm 2 \cdot 9 \\
2 \cdot 3 \pm 0 \cdot 6^{*}\end{array}$ & $\begin{array}{l}\text { acids } \\
8 \cdot 4 \pm 1 \cdot 4^{* * *} \\
26 \cdot 8 \pm 5 \cdot 1^{* * *} \\
8 \cdot 1 \pm 1 \cdot 7\end{array}$ & $\begin{array}{r}5 \cdot 0 \pm 2 \cdot 3 \\
33 \cdot 4 \pm 4 \cdot 6 \\
8 \cdot 9 \pm 2 \cdot 1\end{array}$ \\
\hline
\end{tabular}

Significance of difference: $* \mathrm{P}<0.001$ compared with values at age $1-7$ months ${ }^{* *} \mathrm{P}<0.05,{ }^{* * *} \mathrm{P}<0.01$ compared with values at age $1-2$ years.

creased $(P<0.001)$. Oleic acid $(C 18: 1)$ showed no change in percentage while the children were breast-fed. During weaning the fatty-acid pattern of the subcutaneous fat did not show notable changes except in the proportions of oleic, stearic, and palmitoleic acids $(P<0.01)$.

When the fatty-acid composition of body fat in Tanzanian children during weaning (age 1-2 years) was compared with that in British and Dutch children receiving a mixed diet but of a younger age group (6-12 months), the most important differences were higher proportions of lauric and myristic acids in Tanzanian children $(P<0.001)$ and simultaneously a smaller proportion of the unsaturated fatty acid oleic acid. The percentage of palmitoleic acid was lower in Tanzanian children when compared with Dutch $(P<0.001)$ but not with British children. The proportion of linoleic acid differed significantly from that in British infants only $(P<0.001)$.

The remarkably high proportion of saturated fatty acids in Tanzanian children compared with British and Dutch children is seen from the ratios of unsaturated to saturated acids (table V).

The fatty-acid composition in the two children with kwashiorkor, who received a mixed diet, did not appreciably differ from that of the well-nourished children of the same age group.

TABLE v-Ratios of unsaturated to saturated acids in Tanzanian, British, and Dutch children receiving a mixed diet

\begin{tabular}{|c|c|c|c|}
\hline ed: saturated acids & $\because$ & $\ldots \underset{0.89}{\text { Tanzanian }}$ & $\underset{1 \cdot 17}{\text { British }}$ \\
\hline
\end{tabular}

\section{Discussion}

I compared children in Tanzania, Great Britain, and the Netherlands because of the notable differences in the composition of the fat fed to infants and pregnant women in these three countries. Most Tanzanian infants are breast-fed during the first year of life. During weaning, which starts at the age of about 8-14 months, the Tanzanian child living along the coast receives a thin porridge of cassava or maize flour as supplementary food and continues breast-feeding until the age of 2 or even 3 years, which provides an important source of high-quality protein and essential fatty acids. Most British infants who are not breast-fed are given a formula based on cows' milk to which carbohydrate has been added. Most Dutch infants who are not breast-fed are fed on Almiron, a formula in which the fat in cows' milk has been completely replaced by maize oil (with a linoleic acid content of $58 \%$ ).

In Tanzania the staple food for pregnant and lactating mothers is maize or cassava supplemented with some vegetables. This diet is low in energy, fat, and proteins but relatively rich in carbohydrates. The physical work output of these women is said to be high, although no investigations have been carried out to prove this. Table VI shows the differences in fatty-acid composition between the fat of milk formulas fed to British and Dutch infants ${ }^{6}$ and of human milk from Tanzania and Great Britain. The high percentages of lauric and myristic acids found in the samples of breast milk of Tanzanian mothers when 
TABLE VI-Fatty-acid composition of breast-milk fat fed to Tanzanian infants compared with that fed to British infants and formulas fed to British and Dutch infants $^{6}$ ( $\mathrm{g} / 100 \mathrm{~g}$ total acids)

\begin{tabular}{|c|c|c|c|c|c|}
\hline \multirow{2}{*}{\multicolumn{2}{|c|}{ Fatty acid }} & \multicolumn{2}{|c|}{ Formula feeding } & \multicolumn{2}{|c|}{ Human milk } \\
\hline & & $\underset{\text { Britain* }}{\text { Great }}$ & $\begin{array}{c}\text { The } \\
\text { Netherlands } \dagger\end{array}$ & $\begin{array}{c}\text { Great } \\
\text { Britain }\end{array}$ & Tanzania \\
\hline $\begin{array}{l}\text { Caprylic acid } \\
\text { Capric acid } \\
\text { Lauric acid } \\
\text { Myristic acid } \\
\text { Palmitic acid } \\
\text { Stearic acid }\end{array}$ & $\begin{array}{l}(\mathrm{C} 8: 0) \\
(\mathrm{C} 10: 0)\end{array}$ & $\begin{array}{l}\text { Satur } \\
0 \\
2 \cdot 4 \\
3 \cdot 2 \\
11 \cdot 5 \\
30 \cdot 0 \\
14 \cdot 3\end{array}$ & $\begin{array}{c}\text { sed acids } \\
0 \\
0 \\
0 \\
\text { Trace } \\
10.7 \\
2.0\end{array}$ & $\begin{array}{l}0 \\
1 \cdot 0 \\
4 \cdot 8 \\
6 \cdot 2 \\
23 \cdot 7 \\
6 \cdot 7\end{array}$ & $\begin{array}{r}0.1 \\
1.6 \\
13.7 \\
17.1 \\
23.0 \\
2.3\end{array}$ \\
\hline $\begin{array}{l}\text { Palmitoleic acid } \\
\text { Oleic acid } \\
\text { Linoleic acid } \\
\text { Linolenic acid }\end{array}$ & $(\mathrm{C18}: 3)$ & $\begin{array}{l}\text { Unsatu } \\
2 \cdot 0 \\
31 \cdot 1 \\
1 \cdot 8 \\
\text { Trace }\end{array}$ & $\begin{array}{c}\text { ted acids } \\
\text { Trace } \\
27 \cdot 2 \\
58 \cdot 2 \\
1.6\end{array}$ & $\begin{array}{r}4 \cdot 6 \\
37 \cdot 4 \\
9 \cdot 0 \\
3 \cdot 4\end{array}$ & $\begin{array}{c}2.9 \\
26 \cdot 9 \\
12 \cdot 4 \\
0\end{array}$ \\
\hline
\end{tabular}

*Cow and Gate, Ostermilk, and National Dried Milk.

†Almiron (Nutricia).

compared with British mothers ${ }^{6}$ might be due to the high dietary carbohydrate intake. ${ }^{7 \cdot 12}$ The proportion of the essential linoleic acid in Tanzanian human milk was higher than that found by Widdowson et $a l,{ }^{6}$ suggesting an adequate dietary intake of linoleic acid by the Tanzanian women. The percentages of the easily absorbed medium-chain caprylic acid (C8:0) and capric acid $(\mathrm{C} 10: 0)$, though only small, were higher in the milk of Tanzanian than British mothers."

Information regarding the fatty-acid composition of the subcutaneous fat of fetuses born before term is scarce. Pavey, ${ }^{13}$ in a cross-sectional study of British and Dutch fetuses from 24 weeks' gestation to term, found that the proportion of linoleic acid decreased towards term in both populations, whereas in our study a tendency for an increase was observed between 32 and 37. weeks, which might indicate a better supply of this essential fatty acid from the Tanzanian mother to the fetus in this period. The increase in the proportion of palmitic acid in British and Dutch fetuses agrees with the findings in our study. Proportions of stearic acid did not change over the last trimester in British and Dutch fetuses, whereas they tended to decrease in this study. The proportions of palmitoleic acid remained constant in all the children studied.

An increased intake of myristic acid raises the total plasma cholesterol concentrations and especially the low-density lipoproteins or $\beta$-cholesterol fraction, which is presumed to be one of the factors positively related with coronary heart disease. ${ }^{5}$

In a study on serum lipids in Tanzanian infants (to be published) mean cholesterol concentrations at birth were $1.95 \pm S D 0.38 \mathrm{mmol} / 1(76 \pm 15 \mathrm{mg} / 100 \mathrm{ml})$, equivalent to values in British newborn babies of $2.0 \pm 0.6 \mathrm{mmol} / \mathrm{l}$ $(78 \pm 23 \mathrm{mg} / 100 \mathrm{ml}) .{ }^{14}$ At one year mean cholesterol concentrations were lower in Tanzanian than British children (3.7 and $4.9 \mathrm{mmol} / 1(144$ and $191 \mathrm{mg} / 100 \mathrm{ml})$ respectively). Up to the age of 6 cholesterol concentrations remained virtually constant at $4.0 \mathrm{mmol} / 1(156 \mathrm{mg} / 100 \mathrm{ml})$. If the composition of the subcutaneous fat is assumed to reflect the dietary intake, which was certainly true in our study during breast-feeding, the higher proportions of myristic acid found in Tanzanian children do not correspond with the higher cholesterol concentrations in the first years of life. This contrasts with the Dutch population, in which the diet contains less myristic acid and the serum cholesterol concentration is higher. Although the unsaturated fatty acid linoleic acid may lower serum cholesterol concentrations, a lower percentage of this fatty acid in the breast milk of Tanzanian women $(12 \%)$ compared with the Dutch formula $(58 \%)$ did not correspond with higher cholesterol concentrations in Tanzanian breast-fed infants.

The interpretation of these results is still uncertain. To what extent does the composition of the fat consumed in utero and early life affect the tendency to coronary heart disease in adulthood? Certainly it does not seem justifiable to draw any conclusions on the influence of the individual components of dietary fat on lipid metabolism because this is obviously influenced by many factors.

Theoretically, ${ }^{12}$ the composition of the saturated fatty acids in human milk in Tanzania (with a higher percentage of the medium-chain caprylic and capric acids and of lauric and myristic acids, a relatively high percentage of palmitic acid, and a low percentage of stearic acid) will contribute to even better intestinal absorption of the fats in this milk than the fats in human milk in developed countries. Since calcium absorption, like that of other essential nutrients-for example, fat-soluble vitamins-is closely related to fat absorption, an increased absorption of these nutrients may also be expected in children in Tanzania, which might contribute to the increased speed of growth during the first month of life (as will be shown in a study to be published).

I conclude that differences obviously exist between Tanzanian, British, and Dutch infants in the fatty-acid composition of their body fat. These differences are subtle during the last stage of pregnancy but appear to be most pronounced during infancy and early childhood and are apparently attributable to the nature of the dietary fat in the three countries.

Breast-feeding is still the most common feeding practice for Tanzanian infants during at least the first year of life, and Tanzanian breast milk showed a different fatty-acid composition when compared with the fat of milk formula based on cows' milk, of formula in which the fat in cows' milk had been entirely replaced by maize oil, and even of human milk from Great Britain. This specific fatty-acid composition of the fat in Tanzanian breast milk might ensure even better intestinal absorption by the newborn infant when compared with the fatty-acid composition of human-milk fat in Great Britain.

This survey was supported in part by a grant from de Stichting de Drie Lichten. I am grateful to the following for their help and cooperation: Dr F A Hommes, 'Mr K L Nijdam, Dr H J Degenhart, $\mathrm{Mr} \mathrm{H}$ Visser, and $\mathrm{Mr} \mathrm{N}$ Kempers and his staff. I owe a great debt to Prof J H P Jonxis and Prof $\mathrm{H} \mathrm{K} \mathrm{A} \mathrm{Visser} \mathrm{for} \mathrm{their} \mathrm{suggestions} \mathrm{and}$ criticism, and to Dr R G Pearse for correcting the English text.

Requests for reprints should be addressed to E R Boersma, Sophia Children's Hospital, Gordelweg 160, Rotterdam, The Netherlands.

\section{References}

${ }^{1}$ Keys, A, Atherosclerosis, 1975, 22, 149.

2 Dayton, S, Federation Proceedings, 1971, 30, 849.

${ }^{3}$ Grande, F, South African Medical fournal, 1974, 48, 1660.

4 Murray, M J, et al, British fournal of Nutrition, 1978, 39, 159.

5 Truswell, A S, American fournal of Clinical Nutrition, 1978, 31, 977.

6 Widdowson, E M, et al, British Medical fournal, 1975, 1, 653.

${ }^{7}$ Read, W W C, Lutz, P G, and Tashjian, A, American fournal of Clinical Nutrition, 1965, 17, 180.

${ }^{8}$ Boersma, E R, and Mbise, R L, Tropical and Geographical Medicine. In press.

${ }^{9}$ Lubchenco, L O, Pediatric Clinics of North America, 1970, 17, 125.

${ }^{10}$ Metcalfe, L D, Smitz, A A, and Pelka, J R P, Analytical Chemistry, 1966, 38, 514.

${ }^{11}$ Lipsky, S R, Landown, R A, and Godet, M R, Biochimica et Biophysica Acta, 1959, 31, 336.

12 Jensen, R G, Hagerty, M M, and McMahon, K E, American fournal of Clinical Nutrition, 1978, 31, 990.

${ }^{13}$ Pavey, D, paper read to the Neonatal Society on 21 July 1978, Cambridge. ${ }^{14}$ Darmady, J M, Fosbrooke, A S, and Lloyd, J K, British Medical fournal, $1972,2,685$.

(Accepted 5 February 1979)

ONE HUNDRED YEARS AGO A lamentable accident occurred last week in the Limerick Workhouse. It appears that a patient had been admitted suffering from bronchitis and rheumatic pains, and that a cough-mixture and aconite liniment had been prescribed, both being placed on a shelf over his bed. On the night of the 29th ultimo, the deceased took the liniment by mistake for a dose of the coughmixture, from the effects of which he died next morning. (British Medical fournal, 1879.) 